\title{
Nurturing a "Great Social Organism": School Hygiene, Body Politics, and the State in Late Imperial Russia
}

\author{
Ana Fumurescu* (iD) \\ Department of History, University of Pittsburgh, USA \\ ${ }^{\star}$ Corresponding author. Email: anf123@pitt.edu
}

\begin{abstract}
By the end of the nineteenth century, social hygiene was a topic of great importance for states experiencing fears of national degeneration. The health of children was of particular concern, as it was thought to reflect the future health of the nation. Although this prompted nation-states like France, Germany, the United Kingdom, and the United States to develop intricate theories about the prevention and treatment of childhood illnesses, it was imperial Russia that became an unacknowledged trailblazer in the institutionalization and implementation of school hygiene measures. As this article will show, autocratic Russia's institutions and ideology allowed the tsarist state to surpass its Western neighbors in the drawing up and application of school hygiene measures.
\end{abstract}

Keywords: school hygiene; public health; education; imperial Russia; autocracy; civil society

In June of 1894, the pedagogical periodical Russkaia shkola published an article entitled "The Doctor's Role in School." In it, Dr. Elizaveta Drentel'n surveyed the state of school hygiene on the European continent, citing former French minister of public instruction Léon Bourgeois's claim that with mandatory elementary education must necessarily come measures to guard children's health against the potentially harmful effects of public schooling. According to Drentel'n, this principle was by then acknowledged by all governments, with hardly any country lacking a variety of school hygiene institutions in which public health experts discussed all manner of questions concerning the medical supervision of schools. ${ }^{1}$ Nevertheless, despite the recognition of this issue's importance, relatively little actual progress had been made on this front worldwide-with one notable exception. Unlike most states, including those to which it looked for the latest theories regarding public health, tsarist Russia had taken determined, widespread measures to guard the strength and vitality of its youngest subjects. ${ }^{2}$ Although plagued by many shortcomings, tsarist

\footnotetext{
${ }^{1}$ Elizaveta Drentel'n, "Rol vracha v shkole," Russkaia shkola: obshchepedagogicheskii zhurnal dlia shkoly i cem'i, nos. 5-6 (May and June 1894), 60, https://babel.hathitrust.org/cgi/pt?id=uc1.b3029345\&view=1up\& seq=6\&skin $=2021$.

${ }^{2}$ Drentel'n, “Rol vracha v shkole," 60.

(C) History of Education Society 2022. This is an Open Access article, distributed under the terms of the Creative Commons Attribution licence (https://creativecommons.org/licenses/by/4.0/), which permits unrestricted re-use, distribution, and reproduction in any medium, provided the original work is properly cited.
} 
autocracy was better equipped, both institutionally and ideologically, to tend to the health of its schoolchildren. ${ }^{3}$

Unlike its Western neighbors, whose more visible self-proclaimed liberalism has lent itself well to narratives of progress, the conventional wisdom has tended to portray tsarist Russia as perpetually reforming its way toward a western European gold standard. Western historians have tended to portray Russia's trajectory as "backward" by many measures - pace of industrialization, literacy, political culture, civil societyalways weighing its progress against that of western Europe. Historians of tsarist Russia have tried to correct this impression, acknowledging the shortcomings of the tsarist state while shedding light on the relative progress that was being made, oftentimes at the initiative of individual subjects. At the same time, such scholarship has also pointed out that this notion of Russian backwardness was accompanied by a parallel sense of inferiority vis-à-vis the West, prompting Russian imperial subjects to make too harsh an assessment of their own progress, particularly in the cultural and scientific spheres. ${ }^{4}$

The history of school hygiene, however, tells a different story. Here, tsarist Russia emerges as the protagonist, setting the pace in efforts to medicalize education because, rather than in spite of, its outdated state ideology-an ideology that discursively allowed for a greater convergence of interests between subjects and the state. By comparing the state of school hygiene in late imperial Russia with that in France, Germany, the United Kingdom, and the United States, as well as public discourses concerning social hygiene, this article will argue that school hygiene measures found more widespread public support within tsarist Russia than they did in western Europe and the United States, where similar reforms were not carried out for decades. ${ }^{5}$ Contrary to citizens in more consciously liberal states, subjects in autocratic Russia had more institutional backing and a greater ideological imperative to become active guardians of and contributors to the well-being of the empire's children.

\footnotetext{
${ }^{3}$ In this article, I will specify to which level of schooling-primary, secondary, or upper-I am referring when the distinction is made explicit by my sources. Although the great distinctions between school administration, demographics, and resources at these different levels are certainly necessary for developing a deeper understanding of how school hygiene measures functioned within these states, for the purposes of this article the most significant distinction of which the reader should be aware is that between the Russian case, which aimed to extend school hygiene measures to all educational institutions, and the Western cases surveyed-which did not.

${ }^{4}$ For an example of how these ideas played out within the field of primary education, see Ben Eklof, "Kindertempel or Shack? The School Building in Late Imperial Russia (A Case Study of Backwardness)," Russian Review 47, no. 2 (Winter 1988), 117-43.

${ }^{5}$ This paper is based primarily on public discourse, statistics, and directives that appeared in the periodical press, social hygiene studies, and international hygiene conference publications of the time, and as such does not purport to be an in-depth study of tsarist hygiene policies. Rather, it compares the general structure of the empire's public hygiene institutions and the public discourses surrounding public hygiene and social responsibility within the tsarist state to those institutions and discourses in France, Germany, the United Kingdom, and the United States in order to draw attention to the practical advantages school physicians within imperial Russia had over their Western neighbors. Future research may deepen our understanding of the nature of these advantages by focusing on the specifics of tsarist school hygiene policies, employing archival sources such as the fond (collection) of the Ministry of Education (733, opis' 199) in the Rossiiskii gosudarstvennyi istoricheskii arkhiv (RGIA).
} 
Building on concepts propagated by German and French physicians yet adapting them to the particularities of a sprawling land empire, medical professionals in the late tsarist state wielded the tools of autocracy and rallied the energies of autocratic subjects to turn tsarist Russia into a trailblazer in a domain then considered crucial to the survival and prosperity of any modern state. Although the practical differences between tsarist autocracy and Western liberalism were much less stark than a perfunctory glance might have one believe, their self-proclaimed ideological distinctions allowed tsarist autocracy more freedom to harness individual initiative in service of a greater social good by providing it and its physicians with a shared vocabulary for their often diverging interests. ${ }^{6}$ This vocabulary, steeped in language paralleling the structure and constitution of a state with those of the human body, proved better suited for modernization schemes within the field of school hygiene. Whereas the greater ideological and semantic separation between the state and the individual in the western European and American contexts served to limit the expansion and the scope of school hygiene measures, the vocabulary of autocracy permitted enlarged opportunities for school physicians to make a social impact, for instructors and parents to nurture the vitality of future generations, and for individual subjects to better care for themselves and, by extension, for the wider body politic. ${ }^{7}$ While it did not successfully overcome the many practical shortcomings of the tsarist state-sprawling landmass, bureaucratic sparsity, and inadequate resources, to name a few-this vocabulary nevertheless allowed imperial Russia to make more significant strides within the field of school hygiene than its Western neighbors, if more within the realm of intention than of outcome.

\section{Body Politics}

With the publication of The Birth of the Clinic (1963), Michel Foucault inaugurated a new wave of social medicine scholarship concerned with the ways in which states have sought to monitor and discipline individual minds and bodies. ${ }^{8}$ In particular, this scholarship-like Foucault himself-has been primarily concerned with the ways in which power has changed guise from the outright abuse of absolutist monarchies to the more covert coercion of liberal states. As a result, much has been written about colonial and racial medicine, eugenics, the medicalization of prostitution, and the classification and stigmatization of individuals considered to be physically and mentally deviant from the norms established by nineteenth-century medicine

\footnotetext{
${ }^{6}$ Throughout this paper, I use stark terminology like "autocracy" and "liberalism" for the sake of clarity without, however, wishing to imply a binary distinction between the two, or failing to acknowledge that "autocracy," as such, was understood differently by different actors. I am also not engaging in the debate concerning the definition, form, or utility of the concepts of "absolutism" or "autocracy" as applied to imperial Russia, but rather using these terms to refer to the notion-endorsed by the tsar and generally internalized by his subjects - that society and the state were, at least in theory, coterminous.

${ }^{7}$ In referring to the tsarist "state," I have in mind primarily the tsar and his central administration, understanding the peripheral administrative offices of the state, distant as they were from direct supervision, as a bridge between the central state and the general populace.

${ }^{8}$ See Michel Foucault, The Birth of the Clinic: An Archaeology of Medical Perception (New York: Routledge, 1973).
} 
and psychiatry. ${ }^{9}$ Scholarship on the politicization of bodies and on the coercive potential of medical science has thus usefully blurred the lines between autocracy and democracy, nation and empire, individual and society. ${ }^{10}$ In so doing, this literature has proven invaluable to our understanding of state control of human bodies, particularly of its more subtle and surreptitious manifestations within nascent liberal states.

Yet Foucault's pendulum has swung so far in the direction of absolute (if not absolutist) coercion as to obscure the convergence of interests, and thus the opportunities for cooperation, between individuals and the state. By exaggerating the stature of the state, such scholarship has, wittingly or not, minimized the state's reliance on the support of its individual components-or subjects-for the preservation of its body politic. Within Russian historiography, valuable work on the agency of imperial subjects, on the ideological implications of autocratic subjecthood, and on the practical manifestations of civic action has cleared the path for more explorations of the ambiguous nature of centralized power in tsarist autocracy. ${ }^{11}$ Similarly, literature exploring the traces of civil society in tsarist Russia has pointed toward possibilities for individual initiative and civic action within the confines of the autocratic state. The ongoing debate as to whether tsarist Russia could be said to have had a civil society has hinged largely, as Christopher Eley has pointed out, "on the way one defines the term."12 Although this has elicited much debate within the field of Russian history, a rich body of scholarship now exists that has adopted a more nuanced understanding of the term than that held by historians of western Europe-that is, civil society as a fairly coherent form of autonomous bourgeois social action-to show the myriad opportunities for individual initiative within the tsarist state. Historians like Joseph Bradley, for instance, have focused on the rich activity of voluntary associations,

\footnotetext{
${ }^{9}$ See, for instance: Robert Nye, Crime, Madness, and Politics in Modern France (Princeton, NJ: Princeton University Press, 1984); Christian Promitzer, Sevasti Trubeta, and Marius Turda, eds., Health, Hygiene, and Eugenics in Southeastern Europe to 1945 (Budapest, Hungary: Central European University Press, 2011); Laurie Marhoefer, "Degeneration, Sexual Freedom, and the Politics of the Weimar Republic, 19181933," German Studies 34, no. 3 (Oct. 2011), 529-49; Keely Stauter-Halsted, The Devil's Chain: Prostitution and Social Control in Partitioned Poland (Ithaca, NY: Cornell University Press, 2015); Margaret Cook Anderson, Regeneration through Empire: French Pronatalists and Colonial Settlement in the Third Republic (Lincoln: University of Nebraska Press, 2015); and Andrew C. Isenberg, "An Empire of Remedy Vaccination, Natives, and Narratives in the North American West," Pacific Historical Review 86, no. 1 (Feb. 2017), 84-113.

${ }^{10}$ For a succinct overview of the ideological and practical associations of health and citizenship, see Frank Huisman and Harry Oosterhuis, eds., The Politics of Health and Citizenship (Abingdon, UK: Routledge, 2015). Although the editors and fellow contributors do discuss comprehensive public health care plans undertaken by totalitarian and authoritarian regimes, the volume generally associates public health measures with democratization. "Subjecthood" as a variant on "citizenship" does not appear in the volume, nor does a discussion of public health care policies in tsarist Russia.

${ }^{11}$ See, for instance, Ben Eklof, Russian Peasant Schools: Officialdom, Village Culture, and Popular Pedagogy, 1861-1914 (Berkeley: University of California Press, 1990); Valerie Kivelson, "Muscovite 'Citizenship': Rights without Freedom," Journal of Modern History 74, no. 3 (Sept. 2002), 465-89; and Elizabeth A. Hachten, "In Service to Science and Society: Scientists and the Public in Late-Nineteenth-Century Russia," Osiris: Science and Civil Society 17 (2002), 171-209.

${ }^{12}$ Christopher Eley, "The Question of Civil Society in Late Imperial Russia," in A Companion to Russian History, ed. Abbott Gleason (Malden, MA: Wiley-Blackwell, 2009), 225.
} 
while scholars like Ben Eklof have long shown the many ways in which peasants, provincial instructors, school inspectors, and doctors took the initiative to address the shortcomings of their educational institutions. ${ }^{13}$ Within this body of scholarship, literature on the development of public hygiene in imperial Russia has demonstrated the extent to which imperial subjects, be they medical professionals or newly emancipated peasants, took it upon themselves to make up for the state's shortcomings. ${ }^{14}$

A comparative assessment of school hygiene policies in imperial Russia, western Europe, and the United States has the potential to reveal further instances of individual initiative, as well as of collaboration between subjects and the state. Building on scholarship addressing the nature of civil society in the tsarist state, as well as on public hygiene scholarship that has noted a correlation between a state's ideology and its approach to public health measures, this article will reveal an instance in which the autocratic state and civil society were able to cooperate in pursuit of shared goals. ${ }^{15}$ Although medical professionals in late imperial Russia often disagreed with and were frustrated by the tsarist state's approach to public health and its attitude toward

\footnotetext{
${ }^{13}$ See Joseph Bradley, Voluntary Associations in Tsarist Russia: Science, Patriotism, and Civil Society (Cambridge, MA: Harvard University Press, 2009); and Eklof, Russian Peasant Schools. For further examples of the ways in which the notion of civil society may be applied to the Russian context, see Yanni Kotsonis, States of Obligation: Taxes and Citizenship in the Russian Empire and Early Soviet Republic (Toronto: University of Toronto Press, 2014); and Ekaterina Pravilova, A Public Empire: Property and the Quest for the Common Good in Imperial Russia (Princeton, NJ: Princeton University Press, 2014). For an overview of the historiography on this front, see Adele Lindenmeyr, "'Primordial or Gelatinous'? Civil Society in Imperial Russia," Kritika 12, no. 3 (Summer 2011), 705-20. For discussions on the convergences between absolutist control and liberal reform, see Daniel Beer, Renovating Russia: The Human Sciences and the Fate of Liberal Modernity, 1880-1930 (Ithaca, NY: Cornell University Press, 2008); and Laura Engelstein, The Keys to Happiness: Sex and the Search for Modernity in Fin-de-Siècle Russia (Ithaca, NY: Cornell University Press, 1992).

${ }^{14}$ For overviews of how Russian physicians advocated for themselves and for public health in the aftermath of the Crimean War, see Nancy Frieden, Russian Physicians in an Era of Reform and Revolution, 1856-1905 (Princeton, NJ: Princeton University Press, 2014); and Lisa Kay Walker, "Public Health, Hygiene and the Rise of Preventive Medicine in Late Imperial Russia, 1874-1912" (PhD diss., University of California, Berkeley, 2003), available from ProQuest Dissertations Publishing. For a look at the power struggles between school doctors and teachers as they vied for authority over young bodies, see Andy Byford, "Professional Cross-Dressing: Doctors in Education in Late Imperial Russia (18811917)," Russian Review 65, no. 4 (Oct. 2006), 586-616; and for a thorough discussion of how tsarist subjects employed the act of suicide as a way of affirming autonomy, see Susan Morrissey, Suicide and the Body Politic in Imperial Russia (Cambridge: Cambridge University Press, 2007).

${ }^{15}$ Peter Baldwin explores the ways in which styles of governance affected state responses to epidemics and vice versa, ultimately concluding that a simple binary between authoritarian interventionism and liberal laissez-faire measures does not explain the range of public health policies across the European continent. Peter Baldwin, Contagion and the State in Europe, 1830-1930 (Ithaca, NY: Cornell University Press, 1999). Meanwhile, Andrew Robert Aisenberg explores the dilemma that faced the French Republic in trying to juggle the protection of individual liberties with concerns about public health, in Andrew Robert Aisenberg, Contagion: Disease, Government and the "Social Question" in Nineteenth-Century France (Stanford, CA: Stanford University Press, 1999). Although not the explicit focus, Richard Meckel's Classrooms and Clinics also hints at the relationship between state ideology and school hygiene measures within the American context, explaining that opposition to subsidized school lunches and medical treatment of students hinged in large part on concerns about the proliferation of state socialism. Richard Meckel, Classrooms and Clinics: Urban Schools and the Protection and Promotion of Child Health, 18701930 (New Brunswick, NJ: Rutgers University Press, 2013)
} 
the medical profession, they-as well as other imperial subjects-were able to find a convergence of interests within the field of school hygiene. ${ }^{16}$ This was made possible, in part, by the vocabulary of school hygiene, which reconciled well with that of the autocratic, organic state. ${ }^{17}$ Just as proponents of school hygiene measures compared the social body with that of the individual, so autocratic ideology envisioned the state as a "great social organism," whose vitality depended on the well-being and collaboration of its individual parts.

As this article will show, this organic conception of the state, which squared poorly with liberal state ideologies, provided tsarist Russia and its subjects with a useful vocabulary that would serve to justify and encourage the institutionalization and expansion of medical supervision of student bodies. Looking beyond the borders of individual states and through the open windows of school buildings and international hygiene councils, this article will therefore compare the state of school hygiene in the autocratic tsarist empire with that in the more liberal nations of France, Germany, the United Kingdom, and the United States-then considered trailblazers in social hygiene theory-in order to relegate tsarist Russia to its rightful place in public health scholarship. ${ }^{18}$ By assessing the ways in which school hygiene legislation and implementation in imperial Russia measured up to the medicalization of education undertaken by its Western neighbors, this article will demonstrate that the ideology and institutions of

\footnotetext{
${ }^{16}$ All professional organizations in late imperial Russia faced obstacles from the state in their efforts to organize and carve out for themselves spheres of social action. This was especially true for organizations that highlighted social problems and thereby explicitly or implicitly levied criticisms against the state for its failure to address them. For more on these tensions between medical organizations and the tsarist state, see Frieden, Russian Physicians in an Era of Reform and Revolution, and Engelstein, The Keys to Happiness.

${ }^{17}$ The organic theory of the state-that is, the notion that state (or, in ancient times, "city" or polis) and society are coterminous, akin to a natural organism-emerged in Plato's Republic (375 BCE), was subsequently elaborated upon in Aristotle's Politics $(350 \mathrm{BCE})$, and persisted into the medieval era, when it adopted the vocabulary of the "body politic." Although the analogy of the state as natural organism survived in western Europe well into the nineteenth century, bolstered by the professionalization of the medical sciences, it held neither the same level of prestige nor the same extent of application in more liberal states as it did in tsarist Russia. Whereas in the West the idea of the organic notion of the state was "infected" by the theory of liberal contractarianism-by which citizens made up the artificial body politic through voluntary consent as distinct individuals-in tsarist Russia the ideology of autocracy continued to position imperial subjects as being one with the organism of the state, their interests subjected to the latter. As Laura Engelstein shows in Slavophile Empire: Imperial Russia's Illiberal Path (Ithaca, NY: Cornell University Press, 2009), even those tsarist subjects advocating for liberal reform continued to be shaped by this ideology, demonstrating a greater sense of social responsibility than their Western counterparts. For overviews on the elaboration of this theory and the misconceptions surrounding it, see Phillip Goggans, "Political Freedom and Organic Theories of States," Journal of Value Inquiry 38, no. 4 (Dec. 2004), 531-43; and H. J. McCloskey, "The State as an Organism, as a Person, and as an End in Itself," Philosophical Review 72, no. 3 (1963), 306-26.

${ }^{18}$ Scholarship on public health has tended to focus on national, rather than comparative, studies, obscuring the direction and pace of change within this field worldwide. Those studies that have purported to provide a comparative angle often ignore tsarist Russia or else understate its accomplishments by focusing on its reliance on Western medical knowledge. George Rosen's classic A History of Public Health glosses over the expansion of medical education in tsarist Russia, attributing most of the progress on this front to the subsequent Soviet regime. George Rosen, A History of Public Health (1958; repr., Baltimore: Johns Hopkins University Press, 2015). As mentioned in an earlier footnote, Huismans and Oosterhuis's The Politics of Health and Citizenship fails altogether to address public health policies in tsarist Russia.
} 
Russian autocracy gave greater leeway to physicians and individual subjects within the tsarist state to influence the body politic than had their counterparts in the more liberal states in which school hygiene theories first arose. It will therefore flip Foucault's thesis on its head, considering the ways in which individual initiative could, within the field of school hygiene, coexist and cooperate with autocracy.

\section{De-exoticizing Imperial Russia}

For physicians in imperial Russia, as for the Russian intelligentsia more broadly, actively borrowing ideas from western Europe was both desired and practical-generally viewing western Europe as more culturally advanced than their own state, and lacking sufficient resources and institutions of their own, Russian physicians considered western European medical knowledge a useful tool in their medical bag. Early efforts to stem the tide of epidemic diseases such as cholera within the Russian Empire were modeled on quarantine measures adopted by mercantilist states, and sanitationist notions that proposed filth as a generator of disease were slowly usurped by Robert Koch's and Louis Pasteur's theories of bacteriology. ${ }^{19}$ By the latter part of the nineteenth century, Russian physicians, pedagogues, and statesmen would come to focus on more specific and targeted measures of social hygiene, drawing inspiration from new notions of child development put forth by their neighbors to the west. $^{20}$

This increased concern with children and with childhood development was part of a broader pan-European trend, spurred on by fears of national degeneration. By the latter half of the nineteenth century, low birth rates, demographic losses due to war, and concerns about the potentially detrimental effects of a sedentary and overly-indulgent bourgeois lifetyle on one's physical and moral development led European polities to think concertedly about the vitality of their body politics. France's defeat in the Franco-Prussian War of 1870-1871, the United Kingdom's poor performance in the Boer Wars of 1899-1902, Germany's frustrations in its efforts to become a colonial power, and the United States' increased immigration levels prompted those states to think more seriously about public health measures at the conclusion of the nineteenth century. ${ }^{21}$ Nevertheless, imperial Russia's devastating losses in the Crimean War of 1853-1856 and subsequent shrinking on the international stage alerted the tsarist autocracy earlier and more urgently of the need to conceptualize public health as a holistic, multifaceted project that required the individual and the state to work together symbiotically. ${ }^{22}$

\footnotetext{
${ }^{19}$ Baldwin, Contagion and the State in Europe (2005), 8.

${ }^{20}$ Chief among these were Rousseau's understanding of childhood as a distinct stage of life-see Jean-Jacques Rousseau, Émile, ou De L'éducation (Paris: Classiques Garnier, 1992)—and German pedagogue Friedrich Fröbel's notion of child-rearing as a social task, manifested in his invention of the concept of kindergarten. See Friedrich Fröbel, Froebel's Chief Writings on Education, trans. S. S. F. Fletcher and J. Welton (New York: Longmans, Green \& Co., 1912).

${ }^{21}$ Baldwin, Contagion and the State in Europe (2005); Huismans and Oosterhuis, The Politics of Health and Citizenship, 28; Lora Wildenthal, German Women for Empire, 1884-1945 (Durham, NC: Duke University Press, 2001).

${ }^{22}$ Frieden, Russian Physicians, 56. This conceptualization of public health is a prime example of the organic theory of the state in which tsarist autocracy rooted its ideology.
} 
Since the pace of the institutionalization and professionalization of public hygiene within the tsarist state failed to match physicians' enthusiasm for such measures, medical professionals found ways to develop and elaborate upon their knowledge by joining pan-European and transatlantic networks of social hygiene specialists. Many physicians from within the Russian Empire received their training in European institutions and attended international public health and school hygiene conferences in which they took part in multi-day lectures and discussions with physicians from all over Europe and the world. ${ }^{23}$ Even those physicians who remained within the empire's borders were plugged into this broader transnational network; they eagerly devoured the theoretical expertise of their Western counterparts through specialized periodicals and attended academic lectures in medical universities such as that in Dorpat (modern-day Tartu, Estonia), where the empire's physicians were privy to a German education right at home..$^{24}$ By the end of the nineteenth century, periodicals published within the empire frequently featured articles on school hygiene and child development littered with the names of French and German men of science, citing these specialists but without including their first names-a sure indication of their audiences' familiarity with the personages referenced therein. ${ }^{25}$

If this admiration for their Western counterparts' work had remained at the level of the abstract, Russian physicians and administrators would have been guilty of what nineteenth-century Romanian statesman and pedagogue Titu Maiorescu termed "forms without substance"-straightforward adoptions of foreign notions that lacked meaningful real-life application. But this was not the case. In fact, the tsarist state built upon the theoretical knowledge of Western physicians and made efforts to implement school hygiene measures more quickly and comprehensively than did the states in which those theories were first developed. Drawing on the institutions and ideology of autocracy, imperial Russia became an unacknowledged leader in the implementation of medical inspections in schools, tending to both buildings and bodies, minds and souls, as part of a holistic and multidimensional social project that aimed to nurture the "great social organism" that was the tsarist state. By no means a universally successful project, school hygiene in the final decades of the Russian Empire nevertheless demonstrated the adaptive resiliency of tsarist autocracy. ${ }^{26}$

\section{Forms with Substance}

Although Germany boasted renowned hygiene experts, France claimed for itself the mantle of "the great initiator of hygiene," and the United Kingdom prided itself on

\footnotetext{
${ }^{23}$ Physicians from within the Russian Empire attended transnational conferences such as the International Congress on School Hygiene, which first met in Nuremberg, Germany, in April of 1904, and included representatives from countries from across Europe, Asia, and North and South America.

${ }^{24}$ See Ksenia Kazakova and Tatiana Zhukovskaya, "From St. Petersburg to Dorpat and Back: On Academic Migration and Communication between Universities in the First Half of the 19th Century," Acta Baltica Historiae et Philosophiae Scientiarum 6, no. 2 (2018), 161-70.

${ }^{25} \mathrm{~V}$. Portugalov, "Cherty shkol'noi gigieny," Shkol'noe obozrenie 1, no. 8 (Oct. 1889), 1-5, Rossiiskaia Gosudarstvennaia Biblioteka (RGB), Otdel' Gazet, 1889, II 39/4.

${ }^{26} \mathrm{~N}$. Rumiantseva, “Spornye voprosy vospitaniia," Vospitanie i obuchenie 37, no. 1 (Jan. 1913), 7, https:// babel.hathitrust.org/cgi/pt?id=uiug.30112003984546\&view=1up\&seq=1\&skin=2021.
} 
the professional independence of its physicians, the actual implementation of school hygiene measures in these states proved to be rather slow. ${ }^{27}$ The same may be said for the United States, which, by the turn of the twentieth century, spurred on by concerns with racial purity in the wake of increasing immigration, began to take greater interest in social hygiene, primarily as it applied to areas with high concentrations of (undesirable) immigrant populations. ${ }^{28}$ While all of these states tended to agree on the significance of individual health for the vitality of the body politic as a whole, various impediments-to be discussed below-caused these states to fall short of their very own medical experts' expectations. Although hoping that schools would be "a means to an end-the rearing of healthy citizens," many of the tsarist state's Western neighbors had, on the eve of the First World War, failed to successfully reconcile school hygiene theories with the practical and ideological features of their liberal state ideologies and individualistic economic philosophies. ${ }^{29}$

As such, while France appointed doctors to Parisian elementary schools in the 1830s and 1840s and Germany hired its first school doctor in 1883, none of these initiatives was quick to take root. ${ }^{30}$ The School Medical Board of Paris was only completed in 1883 and had few sister institutions outside the capital, with medical school services being extended to the suburbs of Paris only after $1885 .^{31}$ Even though laws passed in 1886 and 1887 made medical and sanitary inspections obligatory for all French elementary schools, public as well as private, by 1910 the duties of the French school doctor had become centered less on "attention to the school as a whole than to the care of individual scholars." 32 Meanwhile, Germany had only a handful of school doctors, in Frankfurt (1883), Breslau (1888), Dresden (1893), Nuremberg (1897), and Konigsberg (1897), until a successful school inspection scheme in Wiesbaden in 1897 initiated a more consistent wave of school physician appointments, and this only in urban schools. ${ }^{33}$ By 1910, German country schools were "still, to a very large extent, outside the scope of school medical inspection," and upper and private schools were altogether exempt from this requirement. ${ }^{34}$

\footnotetext{
${ }^{27}$ Hugo Selter, Handbuch der Deutschen Schulhygiene (Dresden, Germany: Theodor Steinkopff, 1914), 8-10, https://babel.hathitrust.org/cgi/pt?id=pst.000057646046\&view=1up\&seq=9\&skin=2021; Prosper de Pietra Santa, Organisation des Services de L'hygiène Publique en France (Paris: Bureau de la Societé de Médecine publique, 1887), 18, https://gallica.bnf.fr/ark:/12148/bpt6k6569080w.r=Organisation\%20des\% 20services\%20de\%201\%27hygi\%C3\%A8ne\%20publique\%20en\%20France?rk=21459;2.

${ }^{28}$ See Alan Kraut, Silent Travelers: Germs, Genes, and the Immigrant Menace (Baltimore: Johns Hopkins University Press, 1995).

${ }^{29}$ Theophilus Nicholas Kelynack, ed., Medical Examination of Schools and Scholars (London: P. S. King and Sons, 1910), iii, https://babel.hathitrust.org/cgi/pt?id=uc2.ark:/13960/t3416vw9t\&view=1up\&seq=7\& skin $=2021$.

${ }^{30}$ L. Dufestel, "Medical Examination of Schools and Scholars in France," in Medical Examination of Schools and Scholars, 385; Selter, Handbuch der Deutschen Schulhygiene, 12.

${ }^{31}$ Dufestel, "Medical Examination of Schools and Scholars in France," 385.

${ }^{32}$ Luther Halsey Gulick and Leonard P. Ayres, Medical Inspection of Schools (New York: Charities Publication Committee, 1908), 19, https://babel.hathitrust.org/cgi/pt?id=loc.ark:/13960/t21c2qp2t\&view=1 up\&seq=5\&skin=2021; Dufestel, "Medical Examination of Schools and Scholars in France," 387.

${ }^{33}$ Selter, Handbuch der Deutschen Schulhygiene, 12-13.

${ }^{34}$ Moritz Fürst, "Medical Examination of Schools and Scholars in Germany," in Medical Examination of Schools and Scholars, 378-79.
} 
On the other side of the Channel, although the London School Board appointed a medical officer in 1891, the United Kingdom made no concerted attempts to implement medical inspections of schools until its Education (Administrative Provisions) Act of 1907, which, upon going into effect on January 1, 1908, finally put into place "a compulsory system of medical examination of children in public elementary schools." ${ }^{35}$ Across the pond, Massachusetts remained, by the turn of the twentieth century, the only state in the US to have a compulsory medical inspection law for its schools. ${ }^{36}$ Other states had only partial provisions-if at all-for the medical examination of children, with Vermont requiring that schoolchildren's hearing and vision be tested annually, and Connecticut requiring the same inspections only triennially. ${ }^{37}$ This general lack of consistent and compulsory medical oversight of schools in the United States prompted one 1908 school hygiene report to state that, although "there seem[ed] to be a general impression in America that medical inspection [was] still experimental and on trial, and that [Americans were] leading in this important work," "the reverse of both of these impressions [was] true." 38

Meanwhile, to the east, the tsarist state was taking resolute steps toward the erection of a rationalized and comprehensive program for the medical oversight of its schools. Although the Russian Empire only established a medico-sanitary office under its Ministry of Public Instruction in 1904, it had, as early as 1872, already required permanent doctors in secondary schools, pedagogical colleges, and municipal schools, in addition to medical oversight in zemstvo schools and, by 1889, had initiated concerted efforts to implement consistent medical supervision of all its urban public schooling institutions. ${ }^{39}$ By 1896, "all educational institutions [were]

\footnotetext{
${ }^{35}$ Kelynack, Medical Examination of Schools and Scholars, xiv.

${ }^{36}$ Gulick and Ayres, Medical Inspection of Schools, 1.

${ }^{37}$ Gulick and Ayres, Medical Inspection of Schools, 1.

${ }^{38}$ Gulick and Ayres, Medical Inspection of Schools, $\mathrm{x}$.

${ }^{39}$ G. V. Khlopine, "Les Maladies Scolaires Parmi les Élèves des Établissements D’enseignement Moyens Russes," in Internationales Archiv Für Schulhygiene, vol. 7, ed. T. Lauder Brunton (Leipzig 1911), 280-81, https://babel.hathitrust.org/cgi/pt?id=mdp.39015076622896\&view=1up\&seq=7\&skin=2021; D. Bekariukova, "K voprosu ob organizatsii vrachebnye nadzora $\mathrm{v}$ nachal'nykh uchilishchakh," Vestnik vospitaniia: Nauchno-populiarnyi zhurnal dlia roditelei i vospitatelei 12, no. 9 (1901), 68, https://books.google.com/books? $\mathrm{id}=\mathrm{dpYpAQAAMAAJ \& printsec}=$ frontcover\&hl$=\mathrm{zh}-\mathrm{CN} \&$ source $=$ gbs_ge_summary_r\&cad $=0 \# \mathrm{v}=$ onepage\&q\& $\mathrm{f}=$ false. The zemstva (the Russian plural of zemstvo) were organs of local self-government created in the countryside of European Russia (the more densely populated part of the Russian Empire, west of the Ural Mountains) after the emancipation of the serfs in 1861. These institutions, established in 1864, had a rather ambiguous nature, toeing the line between civil society institutions and organs of the state. Although they were locally elected, they were decreed by the autocracy, and the rules governing them (and their elections) were regulated by the center. Zemstvo schools were schools within the jurisdiction of these provincial administrations. They included primarily elementary schools, but also a smaller number of secondary schools and vocational schools. As Eklof has shown in "The Myth of the Zemstvo School," zemstvo administrations often played a less significant practical role in rural primary education than did the peasants themselves, without whose effort and resources the school expansion campaign might never have gotten off the ground. Ben Eklof, "The Myth of the Zemstvo School," History of Education Quarterly 24, no. 4 (1984), 561-84. For an overview of zemstvo administration and these organs' various competencies, see the contributions to Terence Emmons and Wayne S. Vucinich's edited collection, The Zemtsvo in Russia: An Experiment in Local Self-Government (Cambridge: Cambridge University Press, 1982).
} 
subject to sanitary and medical supervision-state, public, and private [institutions], male as well as female." ${ }^{40}$

With the creation in 1904 of the medico-sanitary department of the Ministry of Public Instruction under the leadership of professor of hygiene G. G. Khlopine, medical supervision of schools was formally institutionalized throughout the Russian Empire, with clear forms, guidelines, and expectations for aspiring school physicians. ${ }^{41}$ Unlike its French, German, British, and American counterparts, the tsarist state was at the forefront of efforts to institutionalize uniform school hygiene measures, making school medical inspections mandatory across the Russian Empire, in both urban and rural areas, in public as well as private schools at all levels of learning. Despite numerous shortcomings, which Russian physicians were quick to point out and lament, school hygiene measures within the Russian Empire nevertheless had taken a more comprehensive form than did those in Western nations. Even when these measures remained at the level of the abstract or were unsatisfactorily implemented due to a lack of personnel and resources, the intentions of the tsarist state on this front surpassed those of other polities by the turn of the twentieth century.

Thus, by the time Dr. A. Nikitin wrote a report on the general state of medical oversight of the empire's schools for the Journal of the Ministry of Public Instruction in September of 1907, the tsarist state had approximately 1,559 registered school physicians, of which 86 were women. ${ }^{42}$ Among these were also a small number of dentists, paramedics, and eye specialists who stepped in when called upon. Overall, these physicians supervised 1,702 educational institutions, composed of 706 elementary schools, 885 secondary schools, and 111 professional schools. ${ }^{43}$ The majority of school physicians were responsible for the inspection of only one educational institution, while smaller numbers simultaneously supervised two, three, and even four schools, and a minority oversaw both urban and zemstvo schools. Nearly half of the empire's school doctors registered at the time of the report had been employed in their posts for fewer than five years, with fewer than one hundred school doctors occupying their posts for twenty-five years or more. ${ }^{44}$ Far from sufficient for the practical medical supervision of all the empire's pupils, the efforts to narrow the gap between legislation and reality were nevertheless concerted and consistent.

Eager to make school hygiene a comprehensive social project with deep roots across the empire's vast expanses, the tsarist state employed a diverse body of physicians. According to Nikitin's report, late imperial Russia's medical community was made up of a wide age range, different religious confessions [or affiliations], and

\footnotetext{
${ }^{40}$ Dr. Mihailova, ed. “Obshchaia organizatsiia nadzora," Vestnik vospitaniia 7, nos. 3-4 (1896), 338.

${ }^{41}$ A. Nikitin, "Statisticheskiia dannyia o shkol'nykh vrachakh v sviazi s voprosom ob organizatsii shkol'no-sanitarnago nadzora," Zhurnal ministerstva narodnago prosveshcheniia 11 (1907), 75, https://runivers.ru/upload/iblock/277/new\%2011.pdf.

${ }^{42}$ Anonymous, "Shkol'noe vrachi i shkol'no-sanitarnyi nadzor $\mathrm{v}$ uchebnykh zabedeniiakh vedomstva ministerstva narodnago prosveshcheniia," Vestnik vospitaniia 19, no. 3 (1908), 69, https://babel.hathitrust.org/cgi/pt?id=mdp.39015076341299\&view=1up\&seq=8\&skin=2021.

${ }^{43}$ Anonymous, "Shkol'noe vrachi," 69.

${ }^{44}$ Nikitin, "Statisticheskiia dannyia," 72-73.
} 
diverse social, educational, and professional backgrounds. The majority of the empire's school doctors were between the ages of thirty and fifty. ${ }^{45}$ Many adhered to the Orthodox confession, but significant numbers also identified with the Jewish, Catholic, Lutheran, Gregorian, Muslim, Protestant, and Anglican faiths, among others. ${ }^{46}$ Although predominantly originating from bourgeois, noble, and clerical backgrounds, some school physicians were also the sons (and daughters) of peasants, officers, clerks, doctors, and pharmacists, to name a few. ${ }^{47}$

At the time of Nikitin's survey, the majority of appointed school doctors had studied at Moscow University and at the Military-Medicine Academy, with smaller contingents of graduates from universities in Kiev, Warsaw, Kazan, and others. ${ }^{48}$ Some had received their medical training abroad, with a handful of school doctors holding diplomas from universities in Paris, Bern, Geneva, Lausanne, Würzburg, Berlin, Zurich, Vienna, Krakow, and Bucharest. ${ }^{49}$ To Nikitin's disappointment, few of these had actually specialized in hygiene and sanitation, the majority holding one or more other specialties. ${ }^{50}$ This cadre of school physicians therefore had "a quite random composition," with specialists in one or more of the following fields: childhood illness, surgery, obstetrics, orthodontics, dermatology, pathology, epidemic diseases, and psychiatry, to name a few. ${ }^{51}$

\section{Serving the Individual and the Community}

Whatever its shortcomings, medical oversight of schools in imperial Russia was qualitatively more comprehensive than that in France, Germany, the United Kingdom, and the United States both in terms of scope and of implementation. State-driven efforts to bring schools under medical supervision targeted all types of institutions of learning, attempting to spread as wide a net as possible over the empire's schools. Unlike school hygiene measures to the west, which tended to focus on large urban areas and to privilege public elementary schools, those in the tsarist state sought early on to reach both public and private schools, at all levels of learning, in cities and countryside alike. The tsarist state also took more concerted measures toward the actual implementation of medical supervision of schools, advocating for the specialized training of its school physicians, engaging the help of local and provincial administrations, and positioning school doctors as employees of the state rather than of private interests. Although many of its plans regarding medical inspection of schools remained unfulfilled, the late imperial Russian state was much more willing than its Western counterparts to envision and lay the groundwork for greater medical oversight of its youngest subjects-and this long before the 1905 Revolution compelled the tsar to turn his previously unquestioned autocracy into a de jure constitutional monarchy.

\footnotetext{
${ }^{45}$ Nikitin, "Statisticheskiia dannyia," 66.

${ }^{46}$ Nikitin, "Statisticheskiia dannyia," 65-66.

${ }^{47}$ Nikitin, "Statisticheskiia dannyia," 65.

${ }^{48}$ Nikitin, "Statisticheskiia dannyia," 67.

${ }^{49}$ Nikitin, "Statisticheskiia dannyia," 67.

${ }^{50}$ Nikitin, "Statisticheskiia dannyia," 71.

${ }^{51}$ Nikitin, "Statisticheskiia dannyia," 68-70.
} 
The explanation for these divergencies seems to lie within the very nature of the autocratic land empire. To begin with, there was the size and scope of the tsarist state. Vast, demographically diverse, and geographically consolidated within one contiguous landmass, imperial Russia was not naturally conducive to civic homogeneity. The wide distances between its various regions, its insufficiently developed infrastructure, and its unevenly distributed population obscured the links between autocratic subjects and widened the gap between society and the state. Although the zemstva were intended to help overcome these challenges, the under-governance of the countryside nevertheless continued to be a real problem, posing serious roadblocks to topdown, uniform implementation of public hygiene measures.

By the turn of the twentieth century, imperial Russia had fewer than four state officials for every 1,000 of its 130 million subjects-less than a third of Germany's numbers. ${ }^{52}$ As Stephen Kotkin notes, this made the tsarist state "top heavy and spread thin," with most of the provincial empire "left to be governed by local society, whose scope of governance, however, was restricted by imperial laws and whose degree of organization varied widely." 53 This might perhaps explain the diversity of the empire's physician corpus-just as schooling has been identified as a tool by which modern states sought to unify its populations, so too school hygiene more specifically, with its comprehensive reach in public and private schools, in urban as well as rural areas, had the potential to promote a unity of practice and of purpose to the empire's heterogeneous population. ${ }^{54}$ Unable to permeate into the daily lives of its vast, heterogeneous population, the tsarist state had to allow its subjects to carry out such measures on their own.

That tsarist administrators and physicians understood the need to foster uniform practices across the empire is apparent in their approach toward the empire's nonethnically Russian, non-Orthodox subjects, known as inorodtsy. ${ }^{55}$ Pedagogical publications emphasized the importance of educating inorodtsy in order to bring them into closer communion with the "Russian spirit," while reports on public health and school hygiene routinely decried the unsanitary conditions of Jewish and Islamic schools. Russian physicians described the former as covered in dirt and insufficiently lit, and the latter as improperly ventilated, cold, and lacking in furniture. ${ }^{56}$ Although some of these complaints were also directed at the empire's other schools, Jewish and Islamic educational institutions were specifically singled out for their hygiene infractions, indicating that they were perhaps more closely scrutinized than were other public schooling institutions. Much as the French, British, and German states more closely policed public health in their colonies, and the United States generally directed

\footnotetext{
${ }^{52}$ Stephen Kotkin, Stalin: Paradoxes of Power, 1878-1928, vol. 1 (New York: Penguin, 2014), 58-59.

${ }^{53}$ Kotkin, Stalin, $58-59$.

${ }^{54}$ The notion that public schooling became a tool by which modern states sought to unify and control their populations was first popularized by Eugen Weber's Peasants into Frenchmen: The Modernization of Rural France, 1870-1914 (Stanford, CA: Stanford University Press, 1976).

${ }^{55}$ The term inorodtsy was typically used by Russian government officials to designate the indigenous populations of Siberia who were not Christian, Jewish, or Muslim.

${ }^{56} \mathrm{~L}$. Vesin, "Sanitarnoe sostoianie shkol' po poslednemu 'Otchetu meditsinskago departamenta," Russkaia shkola, no. 9 (Sept. 1892), 210, https://babel.hathitrust.org/cgi/pt?id=uc1.b3029339\&view=1up\& seq $=11 \&$ skin $=2021$.
} 
its meager school hygiene efforts to areas with high immigrant populations, so the Russian Empire, forced to face the issue of demographic diversity more directly than its Western counterparts, likely looked to school hygiene as a means of more effectively controlling its heterogeneous social body. ${ }^{57}$

These efforts sought to extend throughout the tsarist state and had, at least in theory, vast institutional backing. Among the most important institutions for social hygiene in imperial Russia were the zemstva, which, after their creation in the 1860s, rationalized provincial administration and extended public health to the empire's cultural and political peripheries. As part of the Great Reforms of the 1860 s, the tsarist state created the provincial zemstva to see to tasks that the central government was unequipped to undertake on its own. ${ }^{58}$ Aware of the need to reform or perish, as well as of the practical difficulties of administering such an expansive land empire, the autocratic state began to delegate authority for local administration, education, infrastructure, and public health to these provincial administrations. Neither fully autonomous nor entirely controlled by the center, the zemstva embodied the intersections between autocracy and civil society and zemstvo medicine, drawing upon public health discourse that reconciled well with the organic theory of the state, and managed to carve out for themselves a sphere of influence unique within the system of autocratic-and even zemstvo-governance. As a result, although the central administration was consistently in conflict with these institutions, zemstvo medicine continued to flourish even as the tsarist state began curtailing other zemstvo activities in the 1870 s and 1880 s. $^{59}$

As cholera ravaged the empire in the 1890s and the state realized its inability to provide relief, zemstvo medicine expanded and functioned with less central oversight than programs for popular education or food supply. ${ }^{60}$ This delegation of public health services to zemstvo administrations gave physicians greater opportunities to practice their craft, contributing to the professionalization of the empire's physician corpus. As the zemstva became responsible for "community welfare," which included the administration of orphanages, asylums, vaccinations, and hygiene education, physicians in the empire's provinces acquired new powers and prestige, slowly replacing the folk medicine and midwifery that had previously constituted the bulk of medical knowledge and practice in the Russian countryside. ${ }^{61}$ This delegation of authority to provincial medical professionals squared uncomfortably with the notion of an all-

\footnotetext{
${ }^{57}$ For examples of how Western states attempted to use health and hygiene as a means of bringing their "foreign" populations under control, see examples such as Margaret Cook Andersen, Regeneration through Empire: French Pronatalists and Colonial Settlement in the Third Republic (Lincoln: University of Nebraska Press, 2015); Ann Stoler, Carnal Knowledge and Imperial Power: Race and the Intimate in Colonial Rule (Berkeley: University of California Press, 2002); Lenny A. Ureña Valerio, Colonial Fantasies, Imperial Realities: Realities: Race Science and the Making of Polishness on the Fringes of the German Empire, 1840-1920 (Athens: Ohio University Press, 2019); and Alan M. Kraut, Silent Travelers.

${ }^{58}$ The "Great Reforms" refers to a series of reforms instituted by Tsar Alexander II beginning in 1861 and continuing through the mid-1870s. These included, significantly, the emancipation of the serfs, but also the creation of the provincial zemstvo administrations, as well as reforms of the judicial system, military service, education, and public health.

${ }^{59}$ Frieden, Russian Physicians, 77.

${ }^{60}$ Frieden, Russian Physicians, 90, 96.

${ }^{61}$ Frieden, Russian Physicians, 68.
} 
powerful central government, but reconciled with the ideology of the state as organic organism, made up of interdependent parts that worked together for the well-being of the whole. Within the field of school hygiene, the interests of civil society and autocracy converged within the zemstva-the connecting tissue between society and the state.

School doctors were particularly important ligaments within this system, serving as intermediaries between center and periphery, school child and public health. After the enactment of the Great Reforms, school doctors everywhere, although subordinate to district physicians, served on local pedagogical councils, economic committees, and boards of trustees, on which they had voting power. ${ }^{62}$ They often received their education in state-sponsored institutions, became state employees and, at least in theory, received state salaries. Although at the turn of the twentieth century remuneration for school doctors had been either nonexistent or largely symbolic-with only 1.5 percent of school doctors receiving a yearly salary of more than 1,000 rubles-the new 1904 law formalizing universal medical oversight of the empire's schools set the annual salary for school doctors, male as well as female, at 1,200 rubles, with the possibility of earning additional income for performing supplementary inspections, providing lessons on hygiene, and working in boarding schools. ${ }^{63}$ Even when remuneration was uncertain or insufficient, school physicians in imperial Russia were, as employees of the state, also incentivized through the possibility of acquiring a prestigious rank, gaining rewards for service, receiving free education for their children, and acquiring a state pension. ${ }^{64}$ Therefore, although largely left to their own devices (and resources) while in the field, school doctors in imperial Russia typically had more to gain from their posts than did their Western counterparts.

Given all of these incentives, as well as the emphasis the tsarist state placed on school hygiene training and practice by the first decade of the twentieth century, school physicians in imperial Russia did "not have the right to be at the same time [employed] in any other medical service" while holding a position within schools. ${ }^{65}$ Although this constraint initially made the position of school doctor less attractive, physicians quickly petitioned for higher salaries to offset the potential disadvantages of this restriction. When, in an effort to lure women into lower-paid positions, Dr. Arkhangel'skii portrayed school medical inspection as a woman's job-stating that women had a greater insight into and understanding of childhood illnesses and only they could properly communicate with children-members of the education commission to which he spoke were quick to condemn his "mercantilist calculations" and to state that the importance of the position required that it be properly remunerated regardless of who occupied it. ${ }^{66}$

\footnotetext{
${ }^{62}$ Nikitin, "Statisticheskiia dannyia," 84.

${ }^{63}$ Anonymous, "Shkol'noe vrachi," 69-70; Nikitin, "Statisticheskiia dannyia," 83.

${ }^{64}$ Anonymous, "Shkol'noe vrachi," 70.

${ }^{65}$ Mihailova, Dr., "Polozhenie i prava vrachei srednikh uchebnykh zavedenii," Vestnik vospitaniia. Moscow: Tipo-litografia V. Rixter, 1896. Vol. 7, no. 3-4, 343.

${ }^{66}$ G. Gertsenshtein, "Sanitarnyi nadzor v peterburgskikh gorodskikh shkolakh,” Russkaia shkola, no. 2 (Feb. 1894), 140, https://babel.hathitrust.org/cgi/pt?id=uc1.b3029342\&view=1up\&seq=6\&skin=2021.
} 
This differed significantly from the form and function of school hygiene in the more liberal nation-states of France, Germany, the United Kingdom, and the United States, where physicians had no uniform and widespread system in place to support their work, routinely complained about their lack of authority and remuneration, and had no incentives to view their appointments within schools as worthy of their time and effort. As mentioned above, by 1907, the UK had made medical inspection mandatory only for its public elementary schools, less than a handful of states in America required medical inspection of young schoolchildren, and rural German schools remained largely outside the scope of medical oversight, while upper and private schools in Germany were entirely exempt from inspection. ${ }^{67}$ Although in France school hygiene measures extended to both public and private institutions, French physicians nevertheless decried the largely advisory roles played by French hygiene councils, resented doctors' precarious position at the mercy of politicians' whims, and wished for greater regulatory powers. ${ }^{68}$ They also bemoaned France's attempts to "bind ... the interests of public health to those of commerce" 69 by assigning the responsibility of public hygiene services to the Ministry of Commerce, and criticized the organization of public hygiene services for not "find [ing] space for the [coordinated] action of the state, the department, and the commune." 70

Finally, physicians in all these states were neither properly incentivized nor sufficiently encouraged to work in schools. They routinely complained of abysmal or nonexistent remuneration, which they believed gave "the whole movement an appearance of triviality and fail[ed] to attract competent and experienced men of the medical profession." ${ }^{71}$ School doctors in France, Germany, the United Kingdom, and the United States were largely expected to work on a voluntary basis, were seldom considered fulltime state officials, and often lacked state pensions, making it practically impossible for them to devote their time and attention fully to their nations' schools. ${ }^{72}$ In the United States in particular, physicians were actively discouraged from devoting themselves entirely to school hygiene, as this work was said to be "exceedingly monotonous" and, "if the doctor [was to be] prohibited from having an outside practice, opportunities for increasing his skill and experience [would be] to a great extent cut off." ${ }^{73}$

The position of school doctor within these states was, therefore, much more limited and disincentivized than within imperial Russia, where school physicians were full state employees, received numerous monetary and professional benefits, and held a more prestigious place within the mechanism of tsarist autocracy. By recognizing them-at least in theory-as empowered servants of the state, tsarist Russia also encouraged them to conceive of themselves as servants of community interests. This allowed them to understand their role as a professional estate with responsibility to

\footnotetext{
${ }^{67}$ Fürst, "Medical Examination of Schools and Scholars in Germany," 378-79.

${ }^{68}$ Arthur Armaingaud, De nos institutions d'hygiène publique et de la nécessité de les réformer (Paris: Adrian Delahaye, 1873), 10-12, https://gallica.bnf.fr/ark:/12148/bpt6k6550555g?rk=21459; 2.

${ }^{69}$ De Pietra Santa, Organisation des Services de L' hygiène Publique en France, 16-17.

${ }^{70}$ De Pietra Santa, Organisation des Services de L' hygiène Publique en France, 20.

${ }^{71}$ Gulick and Ayres, Medical Inspection of Schools, 141.

${ }^{72}$ Fürst, "Medical Examination of Schools and Scholars in Germany," 367.

${ }^{73}$ Gulick and Ayres, Medical Inspection of Schools, 147.
} 
the public at large rather than solely to their corporate interests-in other words, it compelled them to serve both the individual and the community.

\section{Tending to Buildings and Bodies}

Once appointed, school physicians in imperial Russia were expected to tend to individual hygiene for the benefit of public hygiene as whole. Public hygiene, whose object was understood to be "the state of health of the social individual-of the people," and whose study and practice was considered to be closely connected to that of other sciences, could not be developed without a focus on individual hygiene. ${ }^{74}$ This latter focus was "the first step in social hygiene," and constituted "the science of the conservation and improvement of the bodily and mental health of a person." ${ }^{\prime 75}$ It consisted of " 1 ) the knowledge and study of the normal composition and function of the human body, 2) the knowledge and study of all that which surrounds the individual, [and] 3) the knowledge and study of the relationship between the individual and his surroundings." 76 Knowing how "to preserve and improve the health of a person, [and] to indicate the causes of ill health and the means of their destruction" were central to the undertaking of individual hygiene. ${ }^{77}$ Like Foucault's clinic, school hygiene in the tsarist state bound the individual to society and made the former's health the business of the latter. As a result, the medical supervision and inspection of the empire's schools became a manifold mission, integrating the physical inspection of buildings and of bodies with that of the world outside school walls, and uniting prevention, diagnosis, and treatment under the same umbrella.

School physicians thus began by tending to the foundation of school hygienethe salubriousness of school buildings. Among the basic duties of the school doctor was the inspection of the air, soil, and water quality in the empire's schools. Some even discouraged the use of wood in school construction because of its predilection for cracks and rodent burrow holes, which made ideal homes for pathogenic microbes, suggesting that smooth brick or cement be used instead, as those materials were more hygienic. ${ }^{78}$ They tried to ensure that school buildings provided purified water, that lavatory facilities were regularly cleaned, and that proper heating and ventilation were maintained, as improper quantities of either could make children susceptible to colds and allergies, or lead to a reduction in their blood oxygen levels. ${ }^{79}$ Physicians further agonized over the square footage of classrooms and the length of desks, trying to ensure that pupils had sufficient space and that the size of their desks corresponded to their age and height. ${ }^{80}$ Heeding German physician

\footnotetext{
${ }^{74}$ Dr. Trushennikov, “O shkol'nom vospitanii s tochki zreniia gigieny," Shkol'noe obozrenie 1, no. 8 (Oct. 1889), 8, RGB, Otdel’ Gazet, 1889, II 39/4.

${ }^{75}$ Trushennikov, "O shkol'nom vospitanii," 8.

${ }^{76}$ Trushennikov, "O shkol'nom vospitanii," 8.

${ }^{77}$ Trushennikov, "O shkol'nom vospitanii," 8.

${ }^{78}$ Portugalov, "Cherty shkol'noi gigieny," 2.

${ }^{79}$ Bekariukova, "K voprosu ob organizatsii vrachebnye nadzora," 70, 72, 74.

${ }^{80}$ A. V. Smirnov, Becedy po gigiene: vedenia na pedagogicheskikh kursakh dlia uchitel'skago personala zemskikh shkol' (Vladimir na Kliazm: Tipo-litografia gubernskoi zemskoi upravy, 1902), 6-34, 43, https://www.prlib.ru/item/398946.
} 
Hermann Cohn's warnings about the proliferation of myopia among schoolchildren, school doctors in the tsarist state also tried to provide for better lighting, encouraged good posture to mitigate eye strain, and prompted teachers to give their pupils frequent breaks from study, preferably to be spent in physical exercise outdoors. $^{81}$

In addition to their roles in inspecting and providing recommendations for the salubriousness of school buildings, school doctors were also tasked with ensuring that schoolchildren themselves were free of contagious diseases and of noncontagious ailments. Aside from encouraging outdoor games, promenades, and lessons in the open air to stave off the dangers of overwork, promote blood oxygenation, and strengthen children's overall physical constitution, school doctors were also expected to tend directly to the physical health of each child by conducting periodical inspections of school buildings, student bodies, instructor corpus, and personnel. ${ }^{82}$ Physicians attached to boarding schools had the additional charge of tending to the health and physical development of pupils by overseeing their food, sleep, clothing, bed linen, exercise, and time spent between lessons. ${ }^{83}$ As a result, medical supervision of schools in imperial Russia aimed toward a holistic supervision that took into consideration the physical conditions both of school buildings and of school bodies, targeting both the outer and inner worlds of the empire's young pupils.

Yet physicians' responsibilities did not end there. To properly oversee the health of schoolchildren, school doctors in imperial Russia were also expected to document and treat illnesses among the student body. They were charged with keeping records of all medical examinations, registering the sick and the deceased, and reporting on the activities they conducted in and around schools. ${ }^{84}$ Besides filling out forms related to the physical conditions of each school building, physicians were also tasked with filling out detailed questionnaires concerning the health of the schoolchildren themselves, answering questions about each student's food intake, weight, height, chest circumference, dental health, prior and current illnesses, physical disabilities, place of living, guardians, performance in school, and ability to engage in physical exercise. ${ }^{85}$ Separate lists, filled out by dentists and optometrists, provided for more specific observations about children's eyesight and dental health. ${ }^{86}$ Finally, physicians were also expected to cure ailing children, providing them with both a diagnosis and a treatment. They were "required to vaccinate and revaccinate, to treat poor sick pupils free of charge, and to manage affairs in case of epidemics." ${ }^{\text {87 }}$ In this way, the responsibilities assigned to school physicians in imperial Russia made the medical inspection of the empire's schools a closed circuit in which school doctors not only supervised and inspected the physical conditions of buildings and of bodies, but

\footnotetext{
${ }^{81}$ Portugalov, “Cherty shkol'noi gigieny," 2; P. Lesgaft, "Referat po fizicheskomu vospitaniiu," Shkol'noe obozrenie 1, no. 3 (Sept. 1889), 6, RGB, Otdel’ Gazet, 1889, II 39/4.

${ }^{82}$ Nikitin, "Statisticheskiia dannyia," 77.

${ }^{83}$ Nikitin, "Statisticheskiia dannyia," 77.

${ }^{84}$ Nikitin, "Statisticheskiia dannyia," 77.

${ }^{85}$ Nikitin, "Statisticheskiia dannyia," 78.

${ }^{86}$ Nikitin, "Statisticheskiia dannyia," 79.

${ }^{87}$ Gulick and Ayres, Medical Inspection of Schools, 21.
} 
also often had the first and final word on what jeopardized the health of schoolchildren and what prescription would provide the best cure.

This situation differed considerably from that in western and central Europe. By 1910, German school hygienists had still "as yet confined [their] efforts to medical inspection and [had] gone only a little way toward medical supervision . . . towards which medical inspection is only the preliminary step" [emphasis in original]. ${ }^{88}$ While they complained of their curtailed authority in regard to school bodies and lamented the complete lack of hygienic supervision of school buildings, their French counterparts felt that they were expected to give too much attention to "the school as a whole than to the care of the individual scholars." 89 In the United Kingdom, although British education policy had, by 1907, begun to operate under the premise that "it is a great deal cheaper to spend pence on children than pounds on paupers," the "medical examination of school children [was] still in the experimental stage." 90 No comprehensive examination of schoolchildren's physical health was at that point undertaken in the United States.

Furthermore, and perhaps most significantly, school doctors in these states were not only curtailed in their efforts to inspect schoolchildren but were also explicitly prevented from offering treatment. Among the factors contributing to this was the protective stance of individual physicians in France, Germany, the United Kingdom, and the United States, who, encouraged in their private practice by their states' economic imperatives, were quick to guard their incomes against the encroachment of school doctors whose foray into medical treatment threatened to draw patients, and therefore income, away from their colleagues in private practice. This was certainly the case in Germany, where physicians in private practice explicitly framed their opposition to medical treatment in schools around their belief that this would entail a "curtailment of their own practice." 91 On the other hand, the tsarist state's overwhelmingly large population and comparatively small cadre of physicians meant that the professional struggle there was more acute between school instructors and school doctors than between physicians in private practice and those employed in schools. Although this particular contention between school instructors and physicians within imperial Russia (as elsewhere) was often cited as an impediment to the proper implementation of school hygiene measures, it at times had the opposite effect of expanding medical oversight in schools by prompting instructors to educate themselves about and monitor their pupils' hygiene. ${ }^{92}$

To the west, even the mere suggestion of school medical oversight and treatment elicited struggles not just between physicians in private practice and those in schools, and between instructors and school doctors, but also between individuals and the state. This is apparent in France, where the ethics of the medical profession

\footnotetext{
${ }^{88}$ Fürst, "Medical Examination of Schools and Scholars in Germany," 380.

${ }^{89}$ Dufestel, "Medical Examination of Schools and Scholars in France," 387.

${ }^{90}$ Kelynack, ed., Medical Examinations of Schools and Scholars, xv.

${ }^{91}$ Fürst, "Medical Examination of Schools and Scholars in Germany," 369.

${ }^{92}$ Drentel'n, "Rol vracha v shkole," 65.
} 
demanded that medical inspectors "respect the rights of each and to not encroach upon any one person." ${ }^{\prime 3}$ As late as 1910, the French school doctor was expected to look after and inspect the individual and collective health of schoolchildren, but "he [could] not and ought not [have] given treatment." " His task was to "officially inform the family of the state of health of the student, but his right end[ed] there" - it was up to the father to "freely choose his doctor and to treat his child as he [saw] fit." ${ }^{95}$ It was for these same reasons that French schools, unlike those in the Russian Empire, did not employ medical specialists such as dentists and optometrists, believing that these would make it more difficult to prevent the school from becoming a dispensary or polyclinic. ${ }^{96}$

This ambivalence toward medical treatment within schools was perhaps most starkly expressed in the United States, where the public was more likely to consider the compulsory inspection and medication of school children as a threat that extended beyond parents' freedom of choice in determining how and from whom their child received treatment. As a spokesperson for the National League for Medical Freedom stated in 1912, mandatory medical oversight and treatment of schoolchildren was "fraught with the greatest evils at once to the young, to the citizen, to the nation, and to the cause of scientific advancement." ${ }^{97}$ These opponents of medical inspection and treatment went so far as to denounce these measures as illustrative of an "autocratic spirit"-for them, the ultimate insult. ${ }^{98}$

\section{Laying Strong Foundations}

Yet this "autocratic spirit" did not simply entail a curtailment of individual libertiesat least not in this instance. In tsarist Russia, the archetypal autocracy, the ideology (or "spirit") of autocracy animated a "great social organism" whose individual members were crucial to the strength and vitality of the whole. In its efforts to use school as a means by which "to reach perfection in the physical, moral, and mental condition of its pupils with the goal of making of them more or less perfect people, citizens, fathers, and mothers," the tsarist state enlisted the help of all of its subjects. ${ }^{99}$ Thus, while medical oversight of schools was intended as yet another means by which the autocratic state could mold its young into ideal subjects, this new field of activity could not have been undertaken by the state alone. It required the help of doctors, pedagogues, parents, and students in a communal and holistic project whose boundaries extended from buildings to bodies, outside the confines of school walls, and into the home. In this way, it combined a greater control over young minds

\footnotetext{
${ }^{93}$ Louis Gourichon, Le Rôle du médecin scolaire. Prophylaxie des maladies transmissibles à l'école (Paris: C. Delagrave, 1910), 10, https://gallica.bnf.fr/ark:/12148/bpt6k888926h?rk=21459;2.

${ }^{94}$ Gourichon, Le Rôle du médecin scolaire, 10.

${ }^{95}$ Gourichon, Le Rôle du médecin scolaire, 10.

${ }^{96}$ Gourichon, Le Rôle du médecin scolaire, 10.

${ }^{97}$ B. O. Flower, The Compulsory Medical Inspection of School Children (New York: National League for Medical Freedom, 1912), 4, https://babel.hathitrust.org/cgi/pt?id=uiuo.ark:/13960/t6354vx02\&view=1up\& seq $=3$ \&skin $=2021$.

${ }^{98}$ Flower, The Compulsory Medical Inspection of School Children, 4.

${ }^{99}$ Trushennikov, "O shkol'nom vospitanii," 9.
} 
and bodies with a more significant endowment of individual responsibility for the well-being of society as a whole, thereby demonstrating that autocracy not only could coexist with individual and collective action, but in fact thrived on it.

Parents had "the most difficult role" in this communal affair, with mothers expected "to lay a solid foundation for their children's future upbringing, to give [them] the[ir] initial physical, mental and moral development." ${ }^{100}$ In fact, pedagogues and physicians alike believed that "upbringing begins long before the birth of the child," mothers' spiritual and physical development enveloping "the upbringing of all mankind." ${ }^{101}$ Once children exchanged the confines of the home for those of the schoolhouse, the school would then "erect on the foundation laid by the mother the whole finished building, giving society and the state healthy, intelligent and moral members, capable of serving and of bringing benefit" to the community that nurtured them. ${ }^{102}$ Society and the state were tasked with ensuring the success of this project by embellishing the erected "building," "guard[ing] it from destruction and, consequently, attending to the preservation of health, to the feeding of the mind, and to the maintenance of morality among its members." ${ }^{103}$ The upbringing of children was thus, "from the very beginning the business of the state, which [was], more than any individual, interested in the development of man as a social being." ${ }^{104}$

The individual, having been thus holistically and communally nurtured from birth, would become "his own teacher," "brought up under the influence of society and of the state." 105 While pedagogical philosophy actively discouraged instructors and physicians from "crushing a child's will" by means of fear and punishment, "full freedom of the student [did] not and ought not [have] exist[ed]"-the student was expected "to obey school orders and rules and [. . .] to comply with them, [. . .] get accustomed to work and order and acquire the habit of stifling personal impulses and motivations in the interests of a common cause." ${ }^{106}$ Without learning to curb his/ her egotistical tendencies and develop self-control, a child would grow up to be a drag on society rather than "a useful link." 107 Working together, therefore, the physician and the pedagogue were expected not only "to impart knowledge that would save an individual from those misfortunes and evils that he may encounter due to his ignorance," but also "to direct his spirit, to clarify the rational purpose of life and release him into life with animated willpower so that at the foundation of his life would be a love for humanity and for his native land."108

This idea of a symbiosis between man and society translated quite seamlessly into the notion that "life in society, love and compassion for one's own kind, and mutual

\footnotetext{
${ }^{100}$ Trushennikov, "O shkol'nom vospitanii," 9.

${ }^{101}$ Rumiantseva, "Spornye voprosy vospitaniia," 9.

${ }^{102}$ Trushennikov, "O shkol'nom vospitanii," 9.

${ }^{103}$ Trushennikov, "O shkol'nom vospitanii," 9.

${ }^{104}$ Rumiantseva, "Spornye voprosy vospitaniia," 7.

${ }^{105}$ Trushennikov, "O shkol'nom vospitanii," 9.

${ }^{106}$ O. Rogova, “Shkola i vospitanie,” Russkaia shkola, nos. 5-6 (May and June 1901), 104-5, https://babel. hathitrust.org/cgi/pt?id=uc1.b3029389\&view=1up\&seq=8\&skin=2021; M. Sokolova, “Granitsy shkol'noi distsipliny," Shkol’noe obozrenie 1, no. 2 (Sept. 1889), 10, RGB, Otdel' Gazet, 1889, II 39/4.

${ }^{107}$ Rogova, "Shkola i vospitanie," 104.

${ }^{108}$ A. Solovev, "O vospitanii voobshche," Shkol'noe obozrenie 1, no. 4 (Sept. 1889), 2, RGB, Otdel' Gazet, 1889 , II $39 / 4$.
} 
labor and assistance" constituted "the levers of human success, development, and selfimprovement." 109 Since social consciousness was thought to occupy "first place" in human life, school was considered to be "society in miniature," and tsarist society "an organism [made up of] of living forces;" a well-functioning school was thought to be crucial for preparing children to live a life of public service. ${ }^{110}$ School hygiene was to play an important role in this mission, teaching children that the vitality of their society was dependent on their own physical, moral, and mental well-being. By so intimately linking public health to the health of individual subjects, tsarist autocracy was able to reconcile the individual initiative of non-state actors with community-oriented public service, avoiding the contradictions that plagued liberal, individualistic state ideologies.

Unlike in France, Germany, the United Kingdom, and the United States, where central administrations saw an ideological contradiction between their selfproclaimed liberalism-which divorced individualism from selflessness, making the two mutually incompatible-and the medical supervision of their schoolchildren, in imperial Russia the tsarist state, by virtue (rather than in spite) of its autocratic nature, more successfully integrated individual and collective action into its top-down yet bottom-heavy school hygiene measures. As Laura Engelstein has pointed out, in imperial Russia, "precept and practice were more consistent" and "reformers were spared the ironies of imperfect liberation that so focus Michel Foucault's iconoclastic ire." 111 Understanding individuals to be constitutive elements of society and society to be constitutive of the state, tsarist Russia did not suffer from the same existential crises when seeking to impose uniform and compulsory medical inspection, supervision, and treatment in its schools. As a result of its organic state ideology, which blurred the lines between society and the state, tsarist Russia was able to lay the foundations for a school hygiene system that had the potential to give the state strong, healthy, and loyal workers and soldiers, and the individual, as "a social animal," the chance to feel himself "a member of a great social organism." 112

\section{Conclusion}

School hygiene in imperial Russia was, by the turn of the twentieth century, on a more solid footing than projects of similar designations in France, Germany, the United Kingdom, and the United States, where social medicine was at that point still resting rather uncomfortably on its laurels. The tsarist state not only institutionalized a more uniform and universally applicable system of school medical oversight than did these latter states, but also endowed school doctors with greater influence over school buildings and bodies. Physicians in the empire's schools were charged with inspecting public as well as private institutions, in cities and countryside alike, supervising and offering treatment for ailing student bodies at all levels of learning. Yet they were far from the only ones contributing to this holistic social project-

\footnotetext{
${ }^{109}$ Rogova, "Shkola i vospitanie," 104.

${ }^{110}$ Rumiantseva, "Spornye voprosy vospitaniia," 6; Rogova, “Shkola i vospitanie," 104-5.

${ }^{111}$ Engelstein, The Keys to Happiness, 4, 8.

${ }^{112}$ Rumiantseva, "Spornye voprosy vospitaniia," 7.
} 
parents, instructors, and pupils were also given a role to play in maintaining the overall health of the body politic, being assigned personal responsibility for the vitality of the entire body politic.

While this aspect of imperial Russian school hygiene policy should not be misconstrued as proof of a misunderstood benevolence of autocracy, it nevertheless does highlight the possibilities for individual responsibility and collective action that such a holistic project necessarily entailed. Aware of the size and scope of its envisioned school hygiene measures, the tsarist state delegated responsibilities to ease the process of implementation, and semantically positioned its subjects as not only integral components of the "great social organism" but also as necessary guardians of its well-being. Paradoxically, therefore, it was precisely the autocratic, "backward" nature of the tsarist state, steeped in the ancient and by then outmoded vocabulary of the organic state, that, within the field of school hygiene, provided its subjects with an ideological imperative and institutional backing unmatched by that found in more liberal states. While the state, medical professionals, and individual subjects might have had divergent or even contradictory motivations for participating in this project, they nevertheless shared a vocabulary that allowed for cooperation in safeguarding the health of the empire's youngest, and most vital, subjects. In the end, the "autocratic spirit" so decried by imperial Russia's Western neighbors placed the tsarist state in the lead in efforts to institutionalize school hygiene measures, endowing its subjects with a sense of individual purpose and social responsibility that autocracy, by its very nature, was thought to deny.

Ana Fumurescu is a PhD candidate in the Department of History at Pittsburgh University. She would like to thank Professor James Pickett (University of Pittsburgh) for his invaluable encouragement and advice on this article through its multiple iterations. She would also like to thank Professor Ben Eklof (Indiana University, Bloomington) for his feedback on an early draft of this article, as well as the anonymous reviewers for their constructive and detailed commentary.

Cite this article: Ana Fumurescu, "Nurturing a 'Great Social Organism': School Hygiene, Body Politics, and the State in Late Imperial Russia," History of Education Quarterly 62, no. 1 (February 2022), 61-83. https:// doi.org/10.1017/heq.2021.58. 